\title{
Design and Research on Blended Teaching of English Picture Book Intensive Reading Course
}

\section{Lingling Qin}

\author{
Foreign Languages Department of Yuzhang Normal College
}

Key words: English picture book intensive reading course, Blended teaching, Design

\begin{abstract}
In the teaching of English picture book intensive reading course, adopting the blended teaching method not only can play the advantages of traditional education, but also can play the advantages of network education, to promote the improvement of education effect for English intensive reading course. This paper analyzes the blended teaching, and explores the strategy of design application for blended teaching from several aspects in the teaching of English picture book intensive reading course, to realize the blended teaching mode which has the effective application, to promote the development of English education which has positive significance.
\end{abstract}

In order to achieve the innovative development of English education, must reform the education mode. In the traditional model of English education, teachers made excessive intervention on students' learning activities, the control of the classroom was very strict, neglected the subject position of students' learning, didn't attach importance to the cultivation of students' self-learning ability and innovation ability, caused English education was not ideal. Under the new situation, English education attaches great importance to the application of Internet technology, many teachers also begin to actively carry out English education with the help of the Internet means, this kind of means is the transcendence of the traditional education mode, can highlight the autonomy of students' learning, and can break through the time and space limit of teaching, which has great advantage of application. But blindly relying on the Internet means to carry out education activities, the teacher's leading role has not been paid attention, teacher lacks effective management, guidance and control for students' learning behavior and learning practice process, it also affects the achievement of teaching goal for English education, as a result, the application of Internet technology in English education also has some limitations. But blended teaching model can combine the advantages of traditional teaching and Internet teaching, blended teaching integrates the advantages of traditional teaching and Internet teaching, to avoid some defects and problems in the teaching, this teaching mode applied in the teaching of English picture book intensive reading, can effectively improve the effect of English teaching, to carry out the relevant teaching goal, this teaching mode should be as the important choice for English educators under the new situation.

\section{Understanding of blended teaching}

Blended teaching is the combination of a variety of learning methods, such as the combination of traditional learning method and multimedia teaching method, the combination of individual learning and cooperative learning, etc. With the further development of modern information technology, modern people's understanding for blended teaching is the combination of network technology and traditional learning method, to make both methods can realize the complementary advantages, not only can highlight the dominant position of students' learning, but also can give play to the role of teachers' education guide and education management, to guarantee the effective implementation of education goal.

In particular, blended teaching mode can realize the combination of network learning mode and traditional learning mode. Traditional learning mode has its own advantages, this kind of learning mode can help students to master the contents of the knowledge, is easier to communicate and exchange between teachers and students, is more likely to develop the emotion between teachers 
and students. But in online learning, students need to learn by means of Internet technology. Network learning resources are very abundant, and the free and easy learning environment can be guaranteed. In this kind of learning, the student's learning main role can be effectively played. To realize the integration of both learning methods, teachers need to set the tasks of autonomous learning for students through the network platform, can use the network means, to enrich the learning resources, to provide the support of learning resources for students. At the same time, through online learning, students can choose their own contents according to their own needs, and can constantly discover problems and solve problems. In this kind of learning, students' autonomous learning consciousness and abilities can be effectively cultivated. Not only that, under the mode of blended teaching, teachers can give full play to the guidance and supervision to the leading role of education, can guide students as the main body of learning activities, and can guide students to learn independently, actively and creatively. The blended teaching fights against the theory of teachers-center or students-center, requires to be able to achieve the combination of teachers' leadership and students' main roles. Teachers should give play to the duty to explain the difficult problems, give full play to the management of teaching organization, and play the role of tracking and evaluating for students' learning. However, students need to play the role of main body for learning, and learn actively, the two sides cooperate with each other and complement each other, to promote the deepening development for education learning activities. The blended teaching combines the advantages of traditional teaching and network teaching, which can achieve the best teaching effect.

\section{Design on blended teaching for English picture book intensive reading course}

The application of blended teaching mode in the teaching of English picture book intensive teaching course, needs to be done the teaching design well. The design of blended teaching includes the following three modules, first is the design of autonomous learning module, second is the design of online tutoring module and third is the design of the face-to-face discussion module.

The design of autonomous module is mainly designed for students. In the design of autonomous learning module, the teachers mainly need to carry on the design for following contents.

(1) Preview the text contents, through the previewing link, students need to master some unfamiliar words and phrases in the text, and can carry on the preliminary understanding for the text theme, and be able to find some questions that students don't understand and make a good mark.

(2) Watch and learn the video materials which uploaded to the Internet teaching platform by teachers and watch some MOOC videos. After learning about related resources, students need to combine the problems identified in the preview period and explore the way of solving problems. After students' self-efforts, if the questions still cannot be solved, students need to submit the related issues to the group leader for a summary, the issues related to the summary should be brought to the classroom through a common discussion to solve.

(3) Students through the network means to search some information related to text contents, through the information of pictures, words, audios and videos for further understanding to the text content, and arrange the collected information resources, to share to the network learning platform as the team achievements.

(4) Students learn the contents of thematic learning modules provided on the online teaching platform and some information resources shared by other students, to broaden the students' knowledge horizon.

(5) Students complete the exercises after homework and self-test through answers, and self-explore the correct answers. If students encountered questions, students should summarize questions to the team leader.

(6) Each week, students log on the relevant online test system platform, conduct online testing, and complete the test exercises which set up by the teachers in the system.

In the design of online tutoring module, the teachers should design the following contents:

(1) The teachers need to enter the forum in the appointed time, communicate with the students and coach the students for online questions. In addition, teachers also need to be able to connect 
with students through WeChat, email or QQ, and provide online tutoring for students at any time.

(2) Teachers should be able to open up various learning topics on the online teaching platform, and guide students to carry out special studies and exercises according to their own learning situations.

(3) Teachers should be able to analyze and solve some problems in the platform system, and make a unified comment on some common problems.

In the design of face-to-face discussion module, the teacher should design the following contents.

(1) The group need to take turns to explain and analyze the text of the unit, and form a report, the specific contents will be discussed by the group members.

(2) The students need to evaluate the content of the group text, and the teachers need to make comments.

(3) The teachers need to raise questions for the content of the text and guide the students to discuss and solve the problems.

(4) Each group need to present problems and exercises which can't be solved in class, and discuss with other group of students, for the problems that students cannot be solved, teachers should assist students to solve.

(5) Take turns giving speeches in groups, and the topic will be self-determined.

(6) Organize some activities between groups, such as English debate activities, drama performances and other activities, through a variety of activities, to enrich the content of English learning, and enrich students' English comprehensive literacy.

\section{The design on assessment and evaluation of blended teaching for English picture book intensive reading course}

The design on assessment and evaluation of blended teaching for English picture book intensive reading course is an important measure to improve the effect of Education. This kind of assessment and evaluation can effectively grasp the students' learning, at the same time, the results of assessment and evaluation can provide support for teachers' future teaching assessment work, to help teachers to analysis the teaching effect, to help to effectively implement the teaching goal. The assessment and evaluation of blended teaching should be able to realize the combination of formative evaluation and summary evaluation. Formative evaluation is mainly to evaluate students' learning online and offline. Online evaluation refers to the use of various network platforms for students to evaluate the situation of autonomous learning, teachers must be able to track students' online learning condition, check the length of the online learning resources, comment on the forum, interact with teachers and students on network platform, comprehensively analyze the difficulty of answering and discussing on the platform, analyze the students' completion of their homework in the autonomous learning and monitoring system, thereby, effectively evaluate online learning conditions of students. For offline evaluation, Teachers mainly evaluate students' performance in class, students' learning attitude, discipline, students' answering questions, discussing problems, and collaboration, etc. to give students a reasonable scores. And the final evaluation is mainly to evaluate the students based on the final exam results, which mainly evaluates the students' achievements. The evaluation results should be objective and fair, and can give a real reaction to the students' learning situation.

\section{References}

[1] Rongrong Ye, Shengquan Yu, Lin Chen. Research on blended teaching for various teaching modes with activities oriented [J]. E-education research. 2012(09).

[2] Wenqian Bai, Wenhao Li, Beilei Chen Research on teaching design of blended teaching based on resource [J]. Modern education technology. 2011(04).

[3] Fang Zhang, Fei Mo. Study on blended learning for middle school English courses [J]. Software 
guide - education technology. 2008(6).

[4] Yun $\mathrm{Xu}$, Rongrong Ma. Research and design on Interactive English learning system in primary and middle schools based on Mobile Learning [J]. China education information. 2010(12).

[5] Yu Pang. Study on group cooperative learning in the application of oral English class in junior middle school [J]. Pedagogical digest. 2017(9). 